JURNAL PENDIDIKAN, p-ISSN 2715-095X, e-ISSN 2686-5041

Volume 30, No.3, Nopember 2021 (369-376)

Online: http://journal.univetbantara.ac.id/index.php/jp

\title{
Analisis Kebijakan Pendidikan Full Day School di Indonesia
}

\author{
Farid Setyawan', Ismail Fauzi ${ }^{2}$, Bunga Fatwa ${ }^{3}$, Hilmi Abdussalam Zaini ${ }^{4}$, Nur \\ Jannah $^{5}$
}

Universitas Ahmad Dahlan, Yogyakarta, E-mail: nurjannah101997@gmail.com

Received: Juni 13, 2021

Accepted: Juli 20, 2021

Online Published: Nopember 08, 2021

\begin{abstract}
Abstrak: Penetapan pembelajaran full day school merupakan kebijakan baru yang memberlakukan pembelajaran di sekolah seharian penuh. Pendidikan yang sifatnya dinamis tentu selalu melakukan pembaharuan demi mengejar ketertinggalan pendidikan Indonesia dengan negara maju. Namun hal ini tentu memerlukan persiapan yang matang agar dapat meminimalisasi timbulnya konflik. Kekhawatiran masyarakat timbul karena dengan adanya full day school ditakutkan dapat merusak tatanan yang sudah ada seperti pengajaran madrasah diniyah. Tentu hal ini akan berdampak pada pemberdayaan masyarakat dan anak-anak. Pada penelitian ini akan membahas lebih lanjut mengenai produk formulasi kebijakan dan problematika penerapan sistem pendidikan full day school. Metode yang digunakan adalah studi literatur, dan menghasilkan bahwa pengelolaan pendidikan tidak bisa dipisahkan dengan kebijakan pendidikan karena keduanya saling bersinergi. Begitupun antara pendidikan dan politik, tidak bisa dipisahkan pula. Keduanya memiliki peranan penting dengan tujuan yang sama yaitu memajukan bangsa. Tujuan, arah, nilai-nilai dan anggaran pendidikan tak luput dari hasil kesepakatan politik.
\end{abstract}

Kata-kataKunci: Kebijakan,Pendidikan, Full Day School

\section{Full Day School Education Policy Analysis in Indonesia}

\section{Farid Setyawan', Ismail Fauzi ${ }^{2}$, Bunga Fatwa ${ }^{3}$, Hilmi Abdussalam Zaini ${ }^{4}$, Nur Jannah $^{5}$}

Ahmad Dahlan University, Yogyakarta, E-mail: nurjannah101997@gmail.com

\begin{abstract}
The establishment of full day school learning is a new policy that enforces full-day school learning. Education that is dynamic is certainly always updating in order to catch up indonesia education with developed countries. But this certainly requires careful preparation in order to minimize the onset of conflict. Community concerns arise because with the full day school is feared to damage the existing order such as teaching diniyah. Of course this will have an impact on the empowerment of the community and children. In this study will discuss more about the product formulation of policies and problems of the implementation of the full day school education system. The method used is literature studies, and results in that the management of education can not be separated from education policy because the two synergize with each other. Even between education and politics, it is inseparable. Both have an important role with the same goal of advancing the nation. The goals, direction, values and education budget are not spared from the results of political agreements.
\end{abstract}

Keywords: Policy, Education, Full Day school 


\section{Pendahuluan}

Pendidikan menjadi entitas yang sangat tinggi nilainya saat ini. Pendidikan senantiasa mengalami perubahan dari masa ke masa dan terus berkembang menyesuaikan zaman. Pengendalian sistem Pendidikan yang ada di Indonesia diawasi langsung oleh KEMENDIKBUD (Kementrian Pendidikan dan kebudayaan) sekaligus selaku pemberi keputusan atau kebijakan Pendidikan. Seiring terjadinya pergantian pemimpin, Menteri Pendidikan tentu memiliki cita-cita, tujuan, dan kebijakan yang berbeda di setiap kelompoknya. Maka tak heran ketika kebijakan yang sudah ada belum sempat terselesaikan, namun sudah ada kebijakan baru yang diputuskan.

Full day schoolmerupakan salah satu dari kebijakan Pendidikan yang ditetapkan oleh Menteri Mendikbud Muhadjir Effendy, tertuang pada peraturan pemerintah Nomor 23 Tahun 2017. Full day school bisa dikatakan sebagai program sekolah yang dilakukan selama sehari penuh yang dimulai dari pukul 07.00 sampai 16.00. Sistem full day schoolsendiri telah lama diterapkan di negara-negara maju sepeti Amerika, Singapura, Korea Selatan dan lain-lain. Dalam pasal 2 ayat 1Pemendikbud No.23 tahun 2017 menyebutkan bahwa dalam pembelajaran Full day school dilaksanakan selama delapan jam dalam satu hari atau 40 jam dalam satu minggu. Dilanjutkan pada pasal 5 ayat 1 disebutkan bahwa hari sekolah digunakan bagi peserta didik untuk melaksanakan kegiatan intrakurikuler, kokurikuler dan ekstrakurikuler. Sementara itu, penerapan full day schoolbertujuan guna membentuk karakter peserta didik sesuai dengan nilai-nilai yang tertulis di UUD 1945, seperti integritas, mandiri, nasionalis, gotong royong dan religious (Taufika, 2019) Dengan adanya full day schoolmembuat peserta didik menghabiskan sebagian besar waktunya di lingkungan sekolah dimana dari waktunya terpakai dari pagi sampai menjelang sore hari bagi peserta didik untuk mengikuti pembelajaran yang sudah terorganisir. Hal ini dapat meminimalisasi anak didik berada di luar sekolah yang bisa sajamereka mengisi waktu luangnya dengan berbagai kegiatan yang kurang bermanfaat atau malah justru menjerumuskan kepada hal-hal yang negatif, ketika anak didik berada di sekolah sudah jelas aman kondisinya karena ada guru yang mengawasi, berbeda apabila di luar sekolah pengawasan anak sudah menjadi tanggung jawab orang tua.

Setiap pembaharuan yang ada tentu tidak mudah untuk memulainya. Meski begitu dinamikadalam dunia Pendidikan tidak boleh berpuas dan berhenti dengan kondisi yang ada saat ini, tetapi harus selalu mencari inovasi dan berkembang. Adanya kebijakan Pendidikan full day school menimbulkan beberapa kekhawatiran masyarakat karena jam pelajaran sehari penuh membuat anak tidak mempunyai waktu untuk belajar diniyah/mengaji yang dilakukan sore hari. Kekhawatiran yang lain yaitu anak tidak dapat bersosialisasi dengan masyarakat di lingkungannya karena jam sekolah yang Panjang. Maka hal ini menjadi perhatian khusus dalam pemberlakuan full day school agar tidak merusak tatanan yang sudah ada di lingkungan masyarakat (Rahem, 2017).

\section{Metode Penelitian}

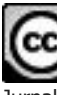


Penulisan jurnal ini menggunakan metode penelitian studi literatur. Penelitian studi literatur dilakukan dengan cara mengumpulkan sumber informasi melalui buku-buku, jurnal, penelitian sebelumnya yang relevan guna menyempurnakan kekurangan pada penelitian yang sudah ada. Sumber data pada penelitian ini terbagi menjadi dua yakni data primer dan data sekunder. Data primer berasal dari data yang dikumpulkan peneliti dari buku atau karya ilmiah yang dijadikan objek penelitian. Sedangkan data sekunder berasal dari sekumpulan data penunjang data primer (Sugiono, 2013). Teknik pengumpulan data dilakukan melalui tiga cara. Pertama editing, peneliti memeriksa keselarasan variabel satu dengan yang lain. Kedua organizing, data yang sudah dikumpulkan harus sesuai dengan kerangka penelitian. Ketiga finding, peneliti menganalisis kembali dari hasil data-data dengan teori, kaidah dan metode ysng dipilih sampai kemudian peneliti dapat menarik kesimpulan permasalahan tersebut (Zed, 2008).

\section{Hasil Penelitian}

Kebijakan merupakan upaya pengawasan agar aturan perundang-undangan yang sudah ditetapkan dapat terselenggara dengan baik dan berjalan efektif. Dalam proses pendidikan tentu menyangkut seluruh institusi pendidikan maka kebijakan pendidikan perlu dibentuk guna menyukseskan tujuan dari pendidikan itu sendiri. Disamping adanya aturan yang seragam, kepala sekolah memiliki wewenang untuk mengeluarkan kebijakan di sekolahnya. Meski begitu keputusan yang dibuat tidak boleh bertentangan dengan aturan yang berlaku.

Kebijakan bersifat dinamis artinya bisa berkembang menyesuaikan kebutuhan. Pada dasarnya kebijakan pendidikan tidak memiliki perbedaan yang signifikan dengan perencanaan pendidikan (educational planning). Kebijakan pendidikan memuat perencanaan yang sudah dipersiapkan jauh sebelum proses pembelajaran berlangsung. Perencanaan pada kebijakan pendidikan dibutuhkan untuk jangka panjang. Berbeda dengan kebijakan pendidikan, perencanaan pendidikan dibuat untuk jangka pendek bisa untuk satu tahun ajaran kedepan.

Menurut peraturan pemerintah nomor 23 tahun 2017 kebijakan merupakan produk kerja politik karena seluruh proses yang ada dalam kebijakan tak lain untuk kepentingan masyarakat bersifat publik. Dalam proses kebijakan hal pertama yang muncul yaitu pendidikan dituntut mampu memenuhi harapan dari masyarakat, dimana untuk mengembangkan pendidikan membutuhkan sinergi para tenaga pendidikan dan aktivis. Kedua, memberi ruang bagi masyarakat untuk memberikan masukan dalam merumuskan kebijakan pendidikan. Ketiga, memperhatikan sumber daya yang ada serta kebermanfaatannya bagi masyarakat. Keempat, meski masyarakat ikut membantu perumusan kebijakan akan tetapi keputusan terbesar ada di tangan pemimpin atau penguasa (Miftah, 2018).

Pengelolaan pendidikan tidak bisa dipisahkan dengan kebijakan pendidikan karena keduanya saling bersinergi. Pada gambar dibawah ini menunjukkan alur dari proses pendidikan. Pertama yaitu proses pendidikan harus berangkat dari analisis teori pendidikan. Dari teori pendidikan menuju ke penerapan teori. Kolom pengelolaan pendidikan juga harus mengkaji teori. Apabila proses pendidikan tidak berjalan seperti alur pada gambar tersebut kemungkinan besar dapat menimbulkan masalah pada kebijakan pendidikan (Danhas, 2021). 


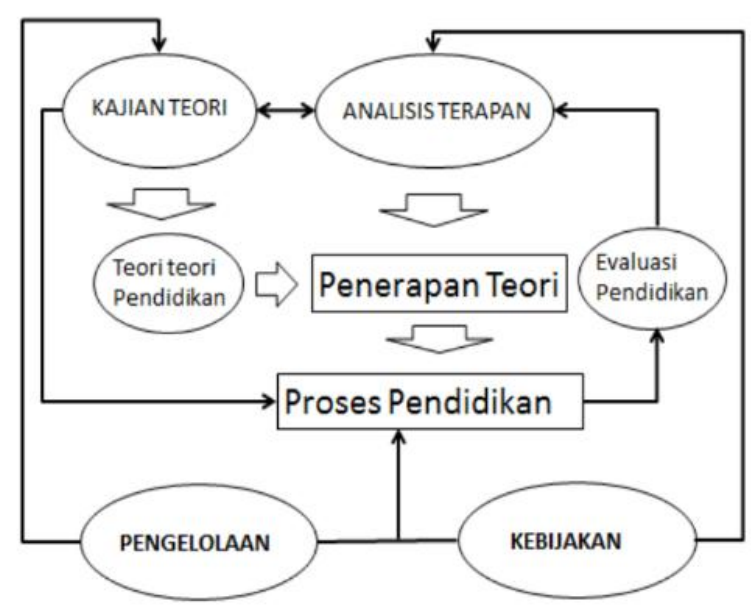

Gambar 1. Perumusan Kebijakan

Perumusan kebijakan atau penyusunan alternatif kebijakan pendidikan termasuk dalam proses perencanaan analisis kebijakan pendidikan (Quade, 1984). Pemilihan alternatif kebijakan menimbang dampak dari segi kepentingan sosial, politik dan ekonomi. Keberadaan kebijakan pendidikan diharapkan menjadi solusi dari permasalahan pendidikan juga dapat terus mengembangkan pendidikan maka perumusan kebijakan pendidikan harus bijaksana dan tidak menimbulkan permasalahan yang lebih rumit (Arwildayanto et al., 2018). Rohman (2012) membagi tiga tahapan perumusan kebijakan pendidikan : 


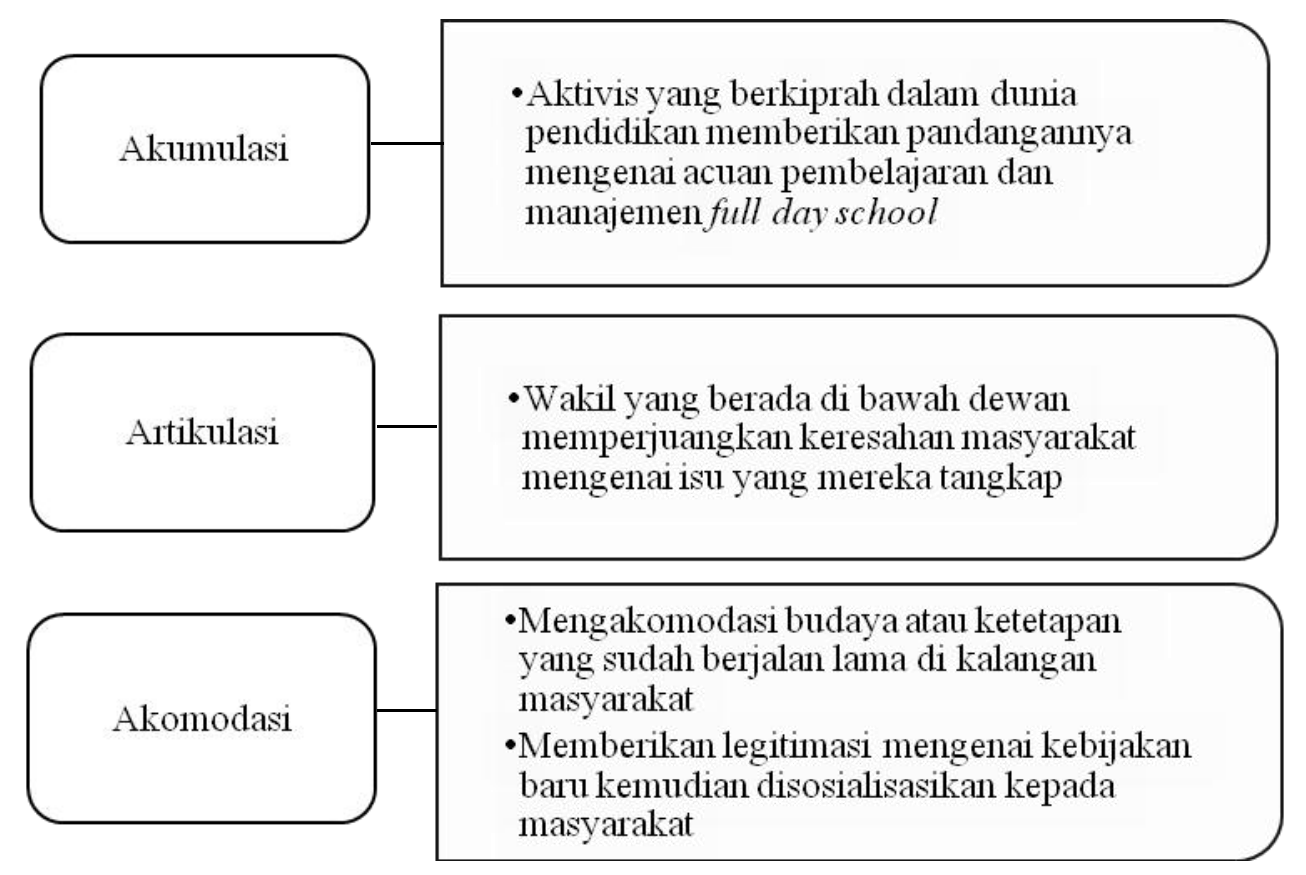

Gambar 2. Tiga Tahapan Perumusan Kebijakan

Seperti yang tertulis pada bagan penjelasan di atas, bisa disimpulkan bahwa antara pendidikan dan politik tidak bisa dipisahkan karena memiliki peranan penting dengan tujuan yang sama yaitu memajukan bangsa. Tujuan, arah, nilai-nilai dan anggaran pendidikan tak luput dari hasil kesepakatan politik. Kedinamisan kebijakan pendidikan tak luput dari adanya kontroversi. Putusan kebijakan bergantung pada siapa yang berkuasa. Pemimpin yang berganti akan mengganti kebijakan sesuai dengan pandangannya. Tak jarang kebijakan lama yang belum terselesaikan harus dihentikan.

Dalam kebijakan pendidikan ada yang disebut dengan kebijakan responsif. Kebijakan responsif adalah akomodasi dan respon dari pemerintah serta masukan dari masyarakat. Pada kebijakan responsif tujuan utamanya adalah memeratakan kesejahteraan dan keadilan masyarakat dan stakeholder yang bersangkutan. AdanyaKebijakan responsifingin memberikan dampak langsung yang dapat dirasakan oleh masyarakat alihalih memajukan suatu negara. Perencanaan kelembagaan pada kebijakan ini yakni memperluas dan penganekaragaman lembaga sehingga lembaga bisa merespon stakeholder dan masyarakat. Keterlibatan masyarakat dalam merumuskan kebijakan akan memudahkan masyarakat menerima dan menerapkan hasil dari kebijakan baru nantinya (Chabibi, 2018)

Kebijakan ortodoks adalah jenis kebijakan yang sangat bertolak belakang dengan kebijakan responsif. Perumusan kebijakan ini tidak melibatkan stakeholder dan masyarakat sama sekali. Seluruh proses mulai dari perencanaan hingga hasil dari kebijakan ortodoks untuk memenuhi kepetingan pemerintah bukan kesejahteraan rakyat. Para pemegang otoritas berwenang hanya akan memikirkan bagaimana kebijakan ini menguntungkan mereka. Padahal hakikatnya keberadaan pendidikan sangat penting bagi masyarakat. Pendidikan merupakan bekal utama untuk menunjang keberhasilan di masa depan kelak. Hal ini menimbulkan pertentangan di masyarakat akibat perbedaan kepentingan diantara keduanya (Suwarto, 2013, 2017). 
Kebijakan full day school merupakan satu dari sekian golongan kebijakan ortodoks karena tidak meletakkan kepentingan masyarakat sebagai tujuannya. Pemegang otoritas bertujuan untuk mencapai visi pemerintah dan prestasi guna mempersiapkan menghadapi tantangan zaman pada era globalisasi. Tidak adanya campur tangan masyarakat dan stakeholder menimbulkan penolakan pemberlakuan full day school. Dengan munculnyafull day school dikhawatirkan bisa menghilangkan pendidikan diniyah atau madrasah yang sudah berjalan lama di lingkungan masyarakat. Ketika pendidikan diniyah dihapuskan tentu akan menghacurkan para pengajarnya serta oragnisasi yang sudah membangun pendidikan diniyah.

Meski terdapat kontroversi, implementasi full day school di Indonesia sudah dijalankan oleh sekolah-sekolah swasta sebelum disahkan Kemendibud. Baru setelah pengesahan sekolah-sekolah negeri mulai menerapkan system full day school juga yang berjalan sampai saat ini.

\section{Pembahasan}

Pengertian fullday school secara bahasa yakni sekolah seharian penuh. Secara etimologi adalah sebagai suatu proses pembelajaran yang berlangsung secara aktif, dan keadaan selama sehari penuh bahkan kurang lebih selama 24 jam. Ada 2 kata kunci dari pengertian yang perlu diketahui: (1). Proses pembelajaran yang berlangsung secara aktif, transformatif, aktif dan sekaligus intensif. Persekolah menggunakan sistem metode fullday school. Yang mana dapat di artikan yakni memaksimalkan seluruh potensi supayabisa mencapai tujuan yang di harapkan dan dapat mengoptimalkan pembelajaran. Transformatif, menggunakan sistem fulldayschool yakni menggunakan proses pembelajaran yang mana ditetapkan agar dapat meningkatkan semua potensi diri yang di miliki pada kepribadian siswa atau murid agar lebih seimbang. Kreatif, sistem yang di gunakan di dalam fullday school yakni terletak pada sistem mengoptimalisasikan memanfaatkan sarana dan prasarana dan dapat mewujudkan psoses pembelajaran yang baik atau kondusif bagi segenap pengembangan potensi siswa. (2). Proses pembelajaran seharian penuh atau dapat disebut dengan sistem pembelajaran 24 jam untuk pelaksanaan proses belajar mengajar yang mana berlangsung secara aktif. Di dalam 24 jam bukan berarti siswa menelaah dan mengkaji berbagai macam aktivitas lainnya tidak mengenal wakti istirahat. Jika proses pembelajaran yang di gunakan 24 jam, maka proses pembelajaran tersebut bukalah proses pembelajaran yang di harapkan yang mana kita ketahui manusia bukanlah robot yang dapat menyanggupi semua kegiatan atau proses pembelajaran selama 24 jam. Yang mana mereka membutuhkan waktu santai, istirahat, melepaskan rasa yang membosankan. Sistem pembelajaran 24 jam yang di maksud yakni melakukan suatu kegiatang yang bermanfaat.

Penerapan program fullday school di beberapa lembaga pendidikan dalam beberapa hari ini didorong oleh rasa keprihatinan dari sistem pendidikan konvensional yang dipandang memiliki banyak kelemahan karena sistem pendidikan konvensional lebih intellectual oriented, sementara hampa dalam segi afektif dan psikomotoriknya(Azizy, 2000).Hal 
demikian terjadi antara lain disebabkan karena jumlah waktu yang diberikan oleh sekolah sangat terbatas dan dalam interaksinya selalu formal. Walaupun begitu, sistem sekolah model konvensional pada batasan tertentu telah memberikan kontribusi yang besar bagi pendidik kita, yaitu : a) sekolah melaksanakan tugas mengajar anak serta memperbaiki dan memperluas tingkah laku si anak didik yang dibawa dari keluarga. b) sekolah mendidik maupun mengajar anak didik menjadi pribadi dewasa susila sekaligus warga Negara. c) sekolah mendidik maupun mengajar anak didik menerima dan memiliki kebudayan bangsa. d) lewat bidang pengajaran sekolah membantu anak didik mengembangkan kemampuan intelektual dan keterampilan kerja, sehingga anak didik memiliki keahlian untuk bekerja dan ikut membangun bangsa Negara. Sehingga pada saat ini sistem fullday school telah menjadi kecenderungan kuat dalam proses edukasi di Indonesia. Banyak dari lembaga pendidikan yang sudah menerapkan sistem ini dengan model yang sangat bervariasi. Istilah yang dipakai juga beragam, seperti ; fullday school, boarding school, dan program ma'ha. Dari sudut pandang sejarah, sistem pembelajaran dari fullday school sebenarnya bukan suatu hal yang baru dalam dunia pendidikan. Sistem ini sudah lama sekali diterapkan dalam tradisi pesantren melalui sistem asrama ataupun pondok, meskipun dalam bentuknya yang tradisional dan sederhana.

Keunggulan fullday school: (1).Pengaruh negatif kegiatan diluar sekolah dapat dikurangi seminimal mungkin karena waktu pembelajaran anak di sekolah lebih lama. (2). Siswa dididik oleh tenaga kependidikan yang terlatih dan professional. (3). Adanya perpustakaan yang nyaman dan representative sehingga membantu meningkatkan prestasi belajar anak. (4). Siswa mendapatkan bimbingan dan pelajaran keagamaan praktis (doa makan, doa-doa harian dan lain-lain.

Kelemahan fullday school: (1). System fullday school sering kali memunculkan rasa jenuh dan bosan pada setiap siswa. Sistem pembelajaran dengan pola fullday school membutuhkan berbagai kesiapan yang matang baik dari fisik, psikologis, maupun intelektual yang baik. Jadwal dan rutinitas kegiatan pembelajaran yang penuh dan penerapan hukuman atau sanksi yang konsisten dalam batas waktu tertentu akan menyebabkan siswa menjadi jenuh. (2). System fullday school memerlukan perhatian dan kesungguhan manajemen bagi pengelola, agar proses pembelajaran pada lembaga pendidikan yang berpola fullday school dapat berlangsung optimal, sangat dibutuhkan perhatian dan curahan pemikiran terlebih dari pengelolanya, bahkan pengorbanan baik fisik, psikologis, material dan lainnya.

\section{Simpulan dan Saran}

Dari pemaparan diatas dapat ditarik kesimpulan bahwa kebijakan full day school merupakan sebuah terobosan pendidikan yang sangat visioner yang dalam penerapannya dapat mengatasi berbagai masalah pendidikan meliputi sisi afektif, kognitif dan psikomotorik, namun setiap kebijakan pendidikan yang tentunya bersifat publik ketika akan diterapkan hendaknya melewati beberapa fase diantaranya pengkajian, jajak pendapat, uji coba dan evaluasi, dalam hal ini kebijakan full day school dilaksanakan secara langsung tanpa persiapan yang matang sehingga berpotensi menimbulkan permasalahan yang lain, selain itu kebijakan pendidikan full day school yang merupakan hasil kontemplasi dari metode pendidikan luar negeri hendaknya disesuaikan terlebih dahulu dengan kondisi 
pendidikan di Indonesia, karena ditakutkan memberikan efek negatif terhadap tatanan pendidikan Indonesia yang telah lama terbangun. Selanjutnya dibalik segudang dari keunggulan sistem pendidikan full day school, penerapan sistem ini juga memiliki beberapa kekurangan diantaranya perlunya kematangan manajemen pengelolaan sekolah, artinya apabila manajemen pengelolaan sekolah tidak matang akan menimbulkan kegagalan pendidikan yang sangat parah, selain itu penerapan sistem pendidikan full day school sangat berpotensi menimbulkan kebosanan dalam diri peserta didik sehingga tujuan pendidikan tidak tercapai secara optimal. Saran yang dapat diberikan didalam kebijakan pendidikan full day school di Indonesia yakni diharapkan kepada peserta didik dan pendidik dapat memahami materi pendidikan kebijakan full day school di Indonesia. Dengan adanya artikel ini diharpkan dapat membantu pembaca dalam memahami bagai mana kebijakan full day school di Indonesia.

\section{Daftar Rujukan}

Arwildayanto, Suking, A., \& Sumar, Tune Sumar, S.Pd., M. P. (2018). Analisis Kebijakan Pendidikan Kajian Teoritis, Eksploratif Dan Aplikatif. In Kebijakan Publik.

Chabibi, M. (2018). Politik Pendidikan Tentang Kebijakan Full Day School (Analisis Karakter Kebijakan Publik). Nidhomul Haq: Jurnal Manajemen Pendidikan Islam. https://doi.org/10.31538/ndh.v3i2.9

Danhas, Y. (2021). Analisis Pengelolaan Dan Kebijakan Pendidikan/Pembelajaran. Deepublish. https://books.google.co.id/books?id=j14kEAAAQBAJ

Miftah, M. (2018). Menakar Kebijakan Full Day School (Studi Analisis Permendikbud No 23 Tahun 2017). Jurnal Perspektif. https://doi.org/10.15575/jp.v2i1.14

Rahem, Z. (2017). Dampak Sosial Pemberlakuan Full Day School (Menimbang MafsadatMaslahat Permendikbud 23/2017 Dan Perpres 87/2017). Al-Murabbi.

Sugiono. (2013). Sugiyono, Metodologi Penelitian Kuantitatif, Kualitatif. In Mode Penelitian Kualitatif.

Suwarto, D. (2013). Pengembangan Tes Diagnostik Dalam Pembelajaran. Yogyakarta: Pustaka Pelajar.

Suwarto, S. (2017). Pengembangan tes ilmu pengetahuan alam terkomputerisasi. Jurnal Penelitian dan Evaluasi Pendidikan, 21(2), 153-161.

Taufika, R. (2019). Implementasi Kebijakan Pendidikan Tentang Full Day School Dalam Menumbuhkan Karakter Sisiwa dI SDIT Bunayya Medan: Studi Deskriptif pada Pelaksanaan Full Day School. Universitas Pendidikan Indonesia.

Zed, M. (2008). Metode Penelitian Kepustakaan. In Yayasan Obor Indonesia. Driyakara, Driyakara Tentang Pendidikan (Yogyakarta: Kanisius, 1980) hlm.,12 Azizy, A. Q. (2000). Islam dan Permasalahan Sosial. Yokyakarta: LKis. 